\title{
Effect of Stirrup Spacing and Polypropylene Fiber Ratio on Behavior of Reinforced Concrete Beams
}

\author{
Alptuğ Ünal1 ${ }^{1 \star}$, Salih Cengiz² ${ }^{2}$ Mehmet Kamanlı ${ }^{1}$ \\ ${ }^{1}$ Department of Civil Engineering, Faculty of Engineering and Natural Sciences, Konya Technical University, 42000, Konya, Turkey \\ 2 Department of Construction, Vocational School of Technical Sciences, Konya Technical University, 42000, Konya, Turkey \\ * Corresponding author, e-mail: aunal@ktun.edu.tr
}

Received: 07 July 2020, Accepted: 12 January 2021, Published online: 22 January 2021

\begin{abstract}
In this study, the effect of the change of stirrup ratio and polypropylene (PP) fiber ratio on the behavior of reinforced concrete beams was investigated. The variables of this study consisting of without stirrup, spacing up to $20 \%, 40 \%$ and $80 \%$ of beam depth as stirrup spacing and $0.125 \%$ and $0.500 \%$ of the weight of reinforced concrete beam were used as PP fiber ratios. In the context of experimental study, 1/2 scaled 12 reinforced concrete beams were tested with 4-point bending mechanism. In the light of the obtained data, the load-displacement, stiffness and energy absorption graphs were plotted. The results were interpreted comparatively. According to the results, it is observed that the PP fiber additive significantly changed the behavior of the reinforced concrete beams, and the fiber effect decreased in proportion to the increase of the stirrup rate. It has been observed that the cracks spread more to the beam surfaces with the increase of PP fibers. In addition, the increase in the fiber ratio especially in the non-stirrup beams increases the bending capacity.
\end{abstract}

Keywords

reinforced concrete beam, stirrup ratio, polypropylene fiber, experimental study, damage mechanic

\section{Introduction}

Concrete, which is the most used building material in the world, has many advantages and disadvantages. Low tensile strength and moment bearing capacity are some of them. Researchers have done many studies to increase the tensile and flexural strengths of concrete. In order to increase the tensile strength of concrete, various fibers were added, and specimens were tested to obtain the desired strength values.

In recent years, various fibers have been produced for different purposes in line with the developing technology. The usage areas of fiber-reinforced concrete vary depending on the structure of the fibrous material $[1,2]$.

Steel fibers are mostly used in industrial facilities, highway pavements, bridge stands, piled foundations, airport runways, explosion-hazardous buildings, hydraulic constructions with cavitation loads, tunnels and galleries [1, 3-7]. Polypropylene fibers have many applications that they are mostly used in concrete road superstructures, industrial flooring, shotcrete applications, airports, fire resistant concrete structures, concrete pipes and military security structures $[1,8]$. In addition, there are many recent studies on polypropylene fibers in the literature. Especially the effects of polypropylene fibers on the shear capacity of reinforced concrete beams were studied by many researchers [9-11]. Besides, researchers have also turned to more specific topics such as the use of polypropylene fibers in precast tunnel segments [12-14], hollow core slabs [15, 16] and doubles [17], in recent years. According to the researches, the effect of both fiber types on concrete is different from each other. Polypropylene fibers give positive effect in bending elements. The energy consumption capacity and the ductility of reinforced concrete beams in which polypropylene fibers are used were higher than most of the fibers [18-21]. Furlan and de Hanai [22] examined the effect of PP and steel fibers on the behavior of reinforced concrete beams. According to their findings, it has been revealed that polypropylene fibers at the same rate provide higher bending strength and deformation capacity than steel fibers. In addition, the only bending damage occurred in beams using PP fiber, while the beams using steel fibers had bending and shear damages. Reinforced concrete beams, the structural elements that transfer loads to the columns, 
are one of the most important structural support elements in buildings where the reinforced concrete structure system is used. The behavior of beams under the internal and external forces of buildings is very important for structural safety. For this reason, the behavior of reinforced concrete beam elements under various loads and conditions should be determined. Ever since the beginning of the usage of reinforced concrete structures, various experimental studies have been conducted by the researchers on the basis of element. Numerous experimental studies have been conducted on reinforced concrete beams [18, 23-34]. These studies aimed to determine the shear resistance by using PP fibers used in reinforced concrete structures.

It is known that stirrup is a very important element in terms of shear safety in reinforced concrete beams. In many studies, the effect of stirrup on the behavior of a reinforced concrete beam was investigated, and important findings have been obtained [35-37]. The beam sizes were chosen to be quite small in the studies conducted only to examine the material characterization. However, the fact that the dimensions of the specimens used in these studies are very small compared to the beam dimensions used in the buildings, and that there is no reinforced concrete reinforcement in these specimens to cause the results to be unrealistic. The reason for using small specimens in experiments is due to the problems experienced in the production of largescale test elements and inadequate test devices. However, the beam sections are larger in real buildings. Therefore, performing experiments using the samples closer to the real beams will bring the test results closer to the real values.

In the light of all these evaluations, an experimental study was performed to measure the flexural strength and energy absorption capacity of reinforced concrete beams with polypropylene fiber. In this study, a total of $1 / 2$ scale 12 reinforced concrete beams, 4 of which are without fiber and 8 of which are PP fiber-reinforced, were produced. The beams were tested under monotonic loading in a 4-point bending mechanism. The stirrup spacing in all beams and the fiber ratio in fiber-reinforced beams are the variables of this study. As a result of this study, load-displacement curves, stiffness graphs and energy absorption graphs of the beams were plotted, and the results were evaluated comparatively. Furthermore, the cracks were plotted during the experiment, and the effects of the cracks on the beam behavior were examined. According to the results, it was observed that the shear behavior of the reinforced concrete beams changed significantly with the change of stirrup spacing and PP fiber ratio.

\subsection{Research significance}

As a result of a comprehensive literature review, there are not many studies on how the ratio of polypropylene fibers to stirrups affects the behavior of reinforced concrete beams. Since stirrups should be used in reinforced concrete beams used in structures, the compatibility of the fibers with stirrups should be investigated. Therefore, this study investigates how different PP fiber ratios with different stirrup spacing affect shear and bending behaviors, failure mode and energy consumption capacity of reinforced concrete beams when used at varying stirrup ratios.

\section{Material and methods}

In this study, the effect of PP fibers on the shear and flexural behaviors of reinforced concrete beams was investigated experimentally. In the context of experimental study, total of 12 reinforced concrete beams were tested with a 4-point bending mechanism. The damages occurred during the experiment were marked, and the behaviors of the specimens were interpreted. Fiber ratio and stirrup spacing are the variables of this study.

While calculating the design shear load carrying capacity in conventional reinforced concrete beams, the cross-sectional area of the stirrups, the tensile strength of the stirrups, the spacing of the stirrups and the tensile strength of the concrete are taken into account. In this study, the tensile strength of concrete was increased by adding PP fiber to reinforced concrete beams, thus the shear force carrying capacity of the beams was increased a little.

While determining the amount of PP fiber, a calculation was made as $3.2 \mathrm{~kg} / \mathrm{m}^{3}$ in one group and $12.8 \mathrm{~kg} / \mathrm{m}^{3}$ in the other group of experiments. While calculating PP fiber ratios, first of all the beam volume was determined, then the estimated beam weight was calculated according to the concrete unit volume weight. Later, the weight of PP fiber to be used in beams was determined according to $3.2 \mathrm{~kg} / \mathrm{m}^{3}$ and $12.8 \mathrm{~kg} / \mathrm{m}^{3}$. The ratio of PP fiber weight to reinforced concrete beam weight used in test elements was $0.125 \%$ in one group, while it was calculated as $0.500 \%$ in another group. Therefore, since $10 \mathrm{~kg} / \mathrm{m}^{3}$ PP fiber has a volume of approximately $1.1 \%, 0.35 \%$ by volume in L2 specimens and $1.40 \%$ by volume in L3 specimens were used. The stirrup spacings are without stirrup, spacing up to $20 \%, 40 \%$ and $80 \%$ of beam depth. The length of the loading point/effective depth ratio (a/d) of the beams was selected as 3 . The certain properties of the specimens were coded, and nomenclature was made. In the test elements, E1 refers to specimens without stirrup, E2 refers 
to spacing up to $80 \%$ of beam depth stirrup spacing, E3 refers to spacing up to $40 \%$ of beam depth stirrup spacing, and E4 refers to spacing up to $20 \%$ of beam depth stirrup spacing. In addition, L1 refers to specimens without fiber, L2 refers to $0.125 \%$ by weight fiber ratio and L3 represents $0.500 \%$ by weight fiber ratio. The characteristics of the test elements are given in Table 1.

\subsection{Material properties}

Concrete mixture calculation was made according to C25/30 (cylinder compressive strength was $25 \mathrm{MPa}$, cubic compressive strength was $30 \mathrm{MPa}$ ). Portland Cement (CEM-I-42.5), fine aggregate, coarse aggregate and water were used in the concrete mixture. The produced concrete was subjected to pressure test using $150 \mathrm{~mm}$ cube and $150 \mathrm{~mm}$ diameter $-300 \mathrm{~mm}$ high cylinder standard samples. The concrete pressure test results are shown in Table 2.

\begin{tabular}{lcccccc}
\multicolumn{7}{c}{ Table 1 General properties of specimens } \\
\hline Beam & $\begin{array}{c}\text { Depth } \\
\text { (mm) }\end{array}$ & $\begin{array}{l}\text { High } \\
(\mathrm{mm})\end{array}$ & $\begin{array}{c}\text { Long. } \\
\text { Rein. }\end{array}$ & $\begin{array}{c}\text { Mont. } \\
\text { Rein. }\end{array}$ & $\begin{array}{c}\text { Stirrup } \\
\text { (radius/ } \\
\text { spacing } \\
(\mathrm{mm}))\end{array}$ & $\begin{array}{c}\text { PP Fiber } \\
\text { Ratio }\end{array}$ \\
\hline B-E1-L1 & 125 & 250 & $3 \phi 8$ & - & - & $0 \%$ \\
B-E2-L1 & 125 & 250 & $3 \phi 8$ & $2 \phi 8$ & $\phi 6 / 200$ & $0 \%$ \\
B-E3-L1 & 125 & 250 & $3 \phi 8$ & $2 \phi 8$ & $\phi 6 / 100$ & $0 \%$ \\
B-E4-L1 & 125 & 250 & $3 \phi 8$ & $2 \phi 8$ & $\phi 6 / 50$ & $0 \%$ \\
B-E1-L2 & 125 & 250 & $3 \phi 8$ & - & - & $0.125 \%$ \\
B-E2-L2 & 125 & 250 & $3 \phi 8$ & $2 \phi 8$ & $\phi 6 / 200$ & $0.125 \%$ \\
B-E3-L2 & 125 & 250 & $3 \phi 8$ & $2 \phi 8$ & $\phi 6 / 100$ & $0.125 \%$ \\
B-E4-L2 & 125 & 250 & $3 \phi 8$ & $2 \phi 8$ & $\phi 6 / 50$ & $0.125 \%$ \\
B-E1-L3 & 125 & 250 & $3 \phi 8$ & - & - & $0.500 \%$ \\
B-E2-L3 & 125 & 250 & $3 \phi 8$ & $2 \phi 8$ & $\phi 6 / 200$ & $0.500 \%$ \\
B-E3-L3 & 125 & 250 & $3 \phi 8$ & $2 \phi 8$ & $\phi 6 / 100$ & $0.500 \%$ \\
B-E4-L3 & 125 & 250 & $3 \phi 8$ & $2 \phi 8$ & $6 / 50$ & $0.500 \%$ \\
\hline
\end{tabular}

Table 2 Concrete pressure test results

\begin{tabular}{lccccc}
\hline $\begin{array}{l}\text { Sample No / } \\
\text { Fiber Ratio }\end{array}$ & $\begin{array}{c}\text { Load } \\
(\mathrm{kN})\end{array}$ & $\begin{array}{c}\text { Cube } \\
\text { Strength } \\
(\mathrm{MPa})\end{array}$ & $\begin{array}{c}\text { Average } \\
\text { Cube } \\
\text { Strength } \\
(\mathrm{MPa})\end{array}$ & $\begin{array}{c}\text { Cylinder } \\
\text { Strength } \\
(\mathrm{MPa})\end{array}$ & $\begin{array}{c}\text { Average } \\
\text { Cylinder } \\
\text { Strength } \\
(\mathrm{MPa})\end{array}$ \\
\hline $1 / 0 \%$ & 867 & 38.53 & 36.1 & 30.82 & 28.88 \\
$2 / 0 \%$ & 760 & 33.78 & & 27.02 & \\
$3 / 0 \%$ & 810 & 36.00 & & 28.80 & \\
$4 / 0.125 \%$ & 832 & 36.98 & 37.35 & 29.58 & 29.88 \\
$5 / 0.125 \%$ & 888 & 39.47 & & 31.57 & \\
$6 / 0.125 \%$ & 801 & 35.60 & & 28.48 & \\
$7 / 0.500 \%$ & 604 & 26.84 & 31.26 & 21.47 & 25.01 \\
$8 / 0.500 \%$ & 705 & 31.33 & & 25.06 & \\
$9 / 0.500 \%$ & 801 & 35.60 & & 28.48 & \\
\hline
\end{tabular}

S420 steel was used in beams as reinforcement. The reinforcement details of the reinforced concrete beams are shown in Fig. 1.

Forta-Ferro brand PP fiber was used in the study. Fiber properties are given in Table 3.

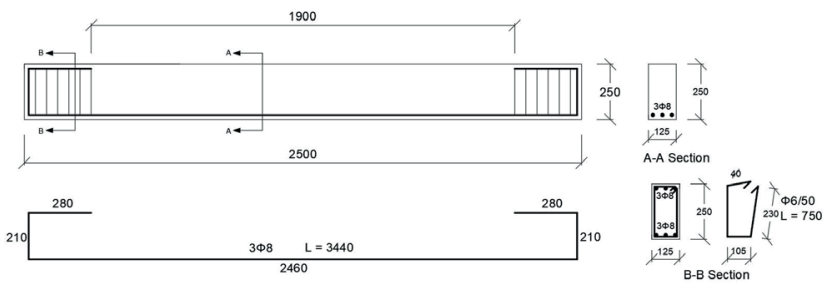

(a)

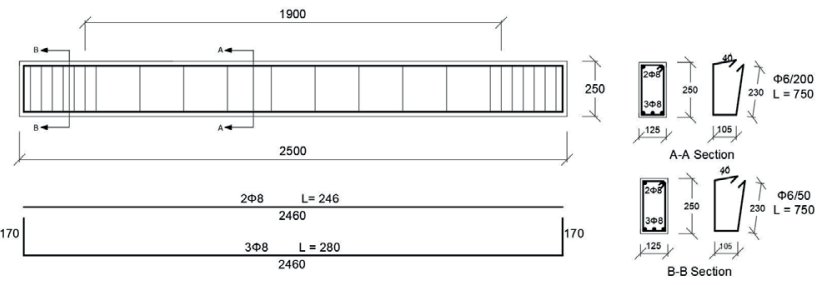

(b)

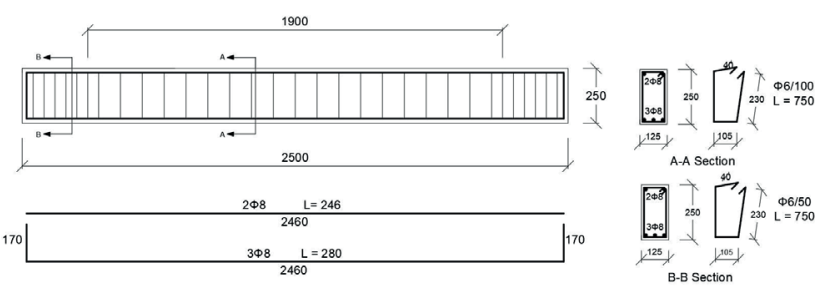

(c)

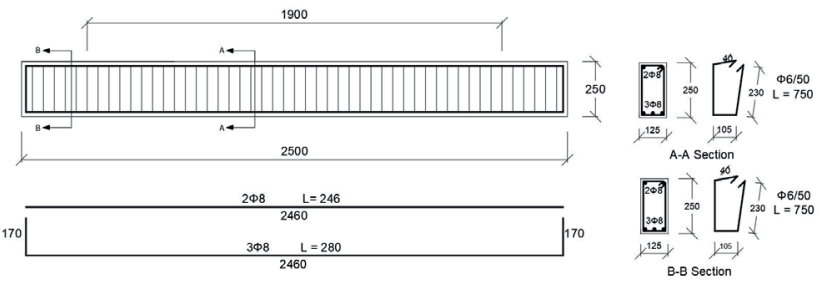

(d)

Fig. 1 Reinforcement rebar detailing: (a) E1, (b) E2, (c) E3, (d) E4 (Measure in $\mathrm{mm}$ )

Table 3 Properties of PP fiber

\begin{tabular}{lccc}
\hline Properties & Value & Properties & Value \\
\hline Raw Material & $\begin{array}{c}100 \% \text { Pure } \\
\text { Copolymer PP/PE }\end{array}$ & Melting point & $162-168^{\circ} \mathrm{C}$ \\
Length & $54 \mathrm{~mm}$ & Burning point & $398^{\circ} \mathrm{C}$ \\
$\begin{array}{l}\text { Tensile } \\
\text { strength }\end{array}$ & $550-750 \mathrm{MPa}$ & $\begin{array}{c}\text { Water } \\
\text { Absorption }\end{array}$ & Zero \\
$\begin{array}{l}\text { Elasticity } \\
\text { Module }\end{array}$ & $5750 \mathrm{MPa}$ & $\begin{array}{c}\text { Acid/Alkali } \\
\text { Resistance }\end{array}$ & Excellent \\
Surface Texture & Deformed Surface & Standard & ASTMC-1116 \\
Density & $910 \mathrm{~kg} / \mathrm{m}^{3}$ & Diameter & $0.677 \mathrm{~mm}$ \\
\hline
\end{tabular}




\subsection{Mechanical characterization test results}

In order to determine the material mechanical characterization, the samples of $150 \times 150 \times 550 \mathrm{~mm}$ were produced according to EN 14651 [38] and tested in a threepoint bending apparatus (Fig. 2). In the experiments, a $100 \mathrm{kN}$ capacity load cell was used for load measurements and two linear variable differential transformers (LVDT) with $0.001 \mathrm{~mm}$ sensitivity for crack mouth opening displacement (CMOD) measurements. The samples are; the control sample, the sample containing no PP fiber, the PP- 0.125 sample containing 0.125 PP fiber by weight, and the PP- 0.500 sample containing 0.500 PP fiber by weight. Table 4 shows the values of flexural test results. In Table 4, the definitions of abbreviations are as follows: $f_{L}$ is the nominal stress at limit of proportionality, $f_{R, 1}$ is the residual strengths at CMOD of $0.5 \mathrm{~mm}$ and $f_{R, 3}$ is the residual strength at CMOD of $2.5 \mathrm{~mm}$.

In Fig. 2, the nominal stress values versus CMOD are given according to EN 14651. PP has been observed that the change in fiber percentages does not have a significant effect on the limit of proportionality. However, changes were observed depending on PP fiber percentages after fracture. PP fibers showed a softening behavior with a sharp load drop after the peak load, followed by an increment of the residual strength. The control sample has completely lost its load carrying capacity after fracture. PP-0.125 and PP-0.500 samples showed decreases in the nominal stress value up to $f_{R, 1}$ after fracture, and after

Table 4 Bending properties of concretes

\begin{tabular}{lccc}
\hline Series & $f_{L}(\mathrm{MPa})$ & $f_{R, 1}(\mathrm{MPa})$ & $f_{R, 3}(\mathrm{MPa})$ \\
\hline Control & 2.61 & - & - \\
PP-0.125 & 2.95 & 1.57 & 1.40 \\
PP-0.500 & 2.81 & 1.53 & 2.41 \\
\hline
\end{tabular}

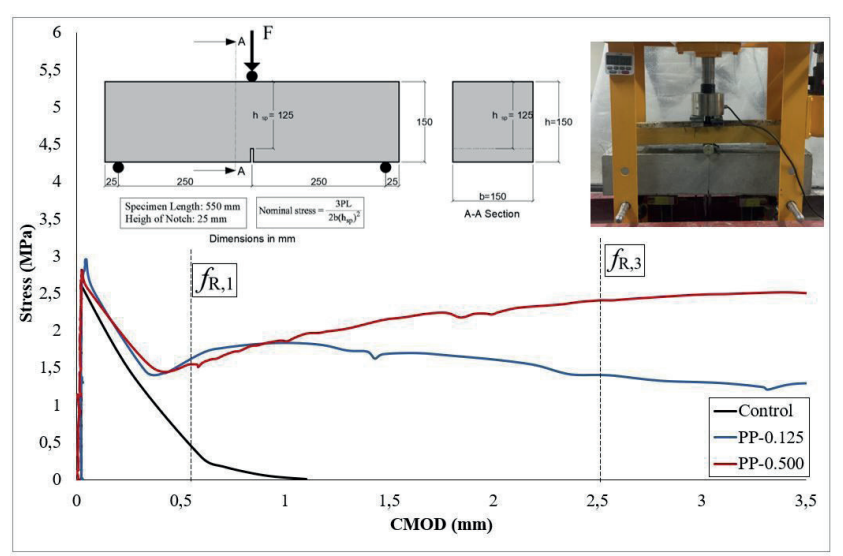

Fig. 2 Nominal stress versus CMOD curves this value, the nominal stress value increased up to $f_{R, 3}$. The nominal stress values of PP- 0.500 and PP-0.125 samples are approximately same in $f_{R, 1}$. However, the nominal stress value of the PP- 0.500 sample is $72 \%$ higher at $f_{R, 3}$ than the PP- 0.125 sample. This indicates that the PP- 0.500 sample has a higher load carrying capacity at advanced displacement levels.

\subsection{Test setup and measurement method}

A total of 12 specimens produced in the scope of the study were tested in Konya Technical University Civil Engineering Department Earthquake Research Laboratory under monotonic loading.

The stress was applied as impulse method with the help of hydraulic jack in the experiments. Load measurements were determined with the help of load cell, and the displacements on the specimens were determined by potentiometric rulers. The capacity of load cells used for the load measurements is $500 \mathrm{kN}$ in pushing and pulling. The displacement values were measured using potentiometric rulers with a capacity of $300 \mathrm{~mm}$. The hydraulic cylinder used to load the specimens has an elongation capacity of $300 \mathrm{~mm}$. The load and displacement values which were read from the measuring instruments during the experiments were transferred to the computer via data gathering system and recorded.

\subsubsection{Test setup}

The specimens used in the experimental study were manufactured in Konya Technical University Civil Engineering Department Earthquake Research Laboratory. After the approximate bearing capacity of the specimens was determined theoretically, the loading system was designed according to the loads that would come to the specimens. The schematic representation of the test setup is shown in Fig. 3.

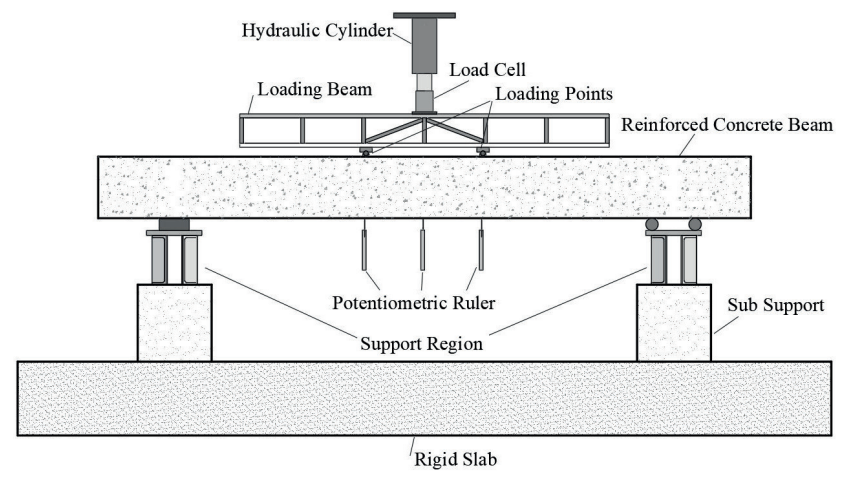

Fig. 3 The test setup 


\subsubsection{Measurement method}

One load cell was used to measure the load, and three potentiometric rulers were used to measure the displacements on the specimens due to the applied load during the experiments. The three potentiometric rulers under the specimens were used to obtain mid-point load-displacement, stiffness and energy graphs.

The potentiometric rulers and the load cell were connected to a data acquisition device that can record 8 data per second. The load and displacement values were first transferred to this device, then to another device called the device gate and finally stored on the computer. The data transferred to the computer was seen on the computer screen by means of a program and the load-displacement curves were plotted simultaneously with the experiment.

The experiments were started with load control, and after the nominal yield value of the system was reached (after the load-displacement curve reached the horizontal position), the experiments were continued with the displacement control. The load was continued until the major damages on the specimens occurred. The loading was carried out with $5 \mathrm{kN}$ load increases up to the nominal yield point in the experiments. After the nominal yield value was reached, the loading was continued with $5 \mathrm{~mm}$ displacement increases up to $50 \mathrm{~mm}$ displacement level, and it was continued with $10 \mathrm{~mm}$ displacement increases after $50 \mathrm{~mm}$ displacement level. The loading was terminated when the capacity of the loading system was reached or when major damages were seen on the beams.

The cracks and damages occurred on the specimens during the experiments were recorded. The load midpoint deflection curves were plotted according to the data obtained from the potentiometric rulers and the load cell. In addition to graphical comparisons, the behavioral patterns of the specimens were also compared. For this purpose, the fracture pattern and the crack distribution occurred during the experiments were examined comparatively.

\subsubsection{Drawing the graphs of the experiments}

The data obtained by the load cell and the potentiometric rulers during the experiments were transferred to a data acquisition device, and then they were processed, various graphs were drawn, and the experimental results were interpreted. The graphics drawn within the scope of the study were created as follows:

Load-Displacement Graph: The displacement values were obtained from the potentiometric ruler placed exactly at the mid-point of the test elements. Furthermore, the data obtained from the load cell located at the mid- point of the beam were divided into 2 , thus, the load values at the loading point were determined. According to these resulted load and displacement values, a load-mid-point displacement graphwas drawn at which the horizontal and vertical axes respectively indicate the displacement values and the load values.

Stiffness Graph: The slope of the curve in the load-central point displacement graphs obtained from each loading during the experiments gives the stiffness of the test specimens. Therefore, for each loading, the angle between the line drawn to this peak and the horizontal axis is of a function of stiffness. The obtained angles constitute the vertical axis, and the loading number constitutes the horizontal axis in the Stiffness Graph.

Cumulative Energy Graph: The energy consumption capacities of the test specimens were determined by calculating the area under the load mid-point displacement graph. After the total energies consumed in the first and second loadings were summed, the cumulative energy graphs were drawn. These values were summed up after each loading, and the cumulative energy graph was drawn. In the graph of cumulative energy consumption, the vertical axis indicates the amount of consumed cumulative energy, while the horizontal axis indicates the central point displacement.

\section{Evaluation and discussion of test results}

\subsection{Specimen behaviors and failure mechanisms}

In order to investigate the effect of PP fiber ratio on the beam behavior, all the test specimens were compared with each other. In the study, flexural beams were produced by taking the shear span to effective depth ratio (a/d) as 3 . The fracture distributions and the resulting damages of the specimens tested in the 4-point bending mechanism are shown in Figs. 4 and 5. In addition, the load-displacement curves obtained from the experiments are given in Fig. 6, Fig. 7 and Fig. 8. The curves were grouped as two groups to examine the effects of the stirrup distance change and the fiber ratio change (Fig. 6 and Fig. 7). In addition, the test results are given in Table 5 and Table 6 . The general beam behavior, collapse modes, strength, stiffness, ductility and energy absorption capacities were determined by using the load-displacement curves of the specimens, and the results were evaluated. The effects of different fiber ratios and different stirrup spacing on the beam behavior were also investigated in the study. 
Table 5 Overall results after tests

\begin{tabular}{llccc}
\hline \multirow{2}{*}{ Specimen } & \multicolumn{2}{c}{ Load Capacity $(\mathrm{kN})$} & \multicolumn{2}{c}{ Deflection $(\mathrm{mm})$} \\
& Yield & Ultimate & At Yield & At Failure \\
\hline B-E1-L1 & 22.69 & 25.18 & 7.85 & 65.29 \\
B-E2-L1 & 25.38 & 28.59 & 13.45 & 180.26 \\
B-E3-L1 & 24.58 & 27.40 & 10.50 & 179.13 \\
B-E4-L1 & 24.65 & 27.86 & 8.96 & 180.35 \\
B-E1-L2 & 25.01 & 27.17 & 9.13 & 96.84 \\
B-E2-L2 & 24.68 & 26.72 & 8.46 & 48.52 \\
B-E3-L2 & 23.40 & 28.21 & 8.50 & 166.21 \\
B-E4-L2 & 23.81 & 28.15 & 8.76 & 165.16 \\
B-E1-L3 & 29.61 & 33.84 & 13.84 & 150.06 \\
B-E2-L3 & 26.49 & 29.47 & 10.47 & 152.06 \\
B-E3-L3 & 24.48 & 29.39 & 10.15 & 180.39 \\
B-E4-L3 & 24.70 & 28.41 & 6.87 & 107.46 \\
\hline
\end{tabular}

Table 6 Overall results after tests

\begin{tabular}{lcccc}
\hline Specimen & $\begin{array}{c}\text { Ductility } \\
\text { Ratio }\end{array}$ & $\begin{array}{c}\text { Yield } \\
\text { Stiffness } \\
(\mathrm{kN} / \mathrm{mm})\end{array}$ & $\begin{array}{c}\text { Energy } \\
\text { Absorption } \\
\text { Capacity } \\
(\mathrm{kN.mm})\end{array}$ & $\begin{array}{c}\text { Failure } \\
\text { Mode }\end{array}$ \\
\hline B-E1-L1 & 8.32 & 2.89 & 1360 & Flexure + Shear \\
B-E2-L1 & 13.40 & 1.89 & 4430 & Flexure \\
B-E3-L1 & 17.04 & 2.34 & 4460 & Flexure \\
B-E4-L1 & 20.13 & 2.75 & 4470 & Flexure \\
B-E1-L2 & 10.61 & 2.74 & 2300 & Flexure + Shear \\
B-E2-L2 & 5.73 & 2.92 & 1210 & Flexure + Shear \\
B-E3-L2 & 19.55 & 2.75 & 4420 & Flexure \\
B-E4-L2 & 18.85 & 2.72 & 4370 & Flexure \\
B-E1-L3 & 10.84 & 2.14 & 4250 & Flexure \\
B-E2-L3 & 14.52 & 2.53 & 4320 & Flexure \\
B-E3-L3 & 17.77 & 2.41 & 4750 & Flexure \\
B-E4-L3 & 15.64 & 3.59 & 2800 & Flexure + Shear \\
\hline
\end{tabular}

The flexural cracks occurred until the yield point was reached after the start of the experiment. All of the specimens reached the yield point. However, B-E1-L1, B-E1-L2, B-E2-L2 and B-E4-L3 collapsed due to shear fracture after reaching the yield point. In these specimens, the shear fracture occurred at the displacement levels of $65.29 \mathrm{~mm}$, $96.84 \mathrm{~mm}, 48.52 \mathrm{~mm}$ and $107.46 \mathrm{~mm}$ respectively, and the experiments were terminated. These specimens showed flexural behavior up to a certain point of the loading and showed shear behavior after that point. In other specimens, the flexural behavior occurred, and the loading was continued as much as the loading system capacity was reached. These specimens failed after the concrete at the outermost of the pressure zone crushed.
The expected behavior was observed in B-E1-L1 and B-E1-L2 at which the shear fractures occurred, since they had no stirrups. The shear fracture occurred at B-E1-L2 and then B-E1-L1 due to fiber additive. That is, a $0.125 \%$ fiber additive can be said to have a positive effect on ductility. Although B-E4-L3 had the lowest stirrup spacing and the highest fiber ratio, it showed an unexpected behavior and collapsed due to shear fracture possibly due to high fiber ratio and the energy accumulated in the fibers. The sudden discharge of energy occurred after a certain point, and a sudden failure occurred with this discharge. Although there were fiber additives in the samples B-E1-L2, B-E2-L2 and B-E4-L3, a sudden collapse occurred sometime after these samples reached the yield point. While the cracks in these samples were observed during the experiment, it was observed that the width of a crack increased compared to other cracks. Thus, in these specimens, the collapse occurred in the places where this large crack occurred. In some experimental studies with PP fibers, it has been stated that a crack can open more than other cracks and collapse may be observed [10, 11, 39, 40]. Although this fracture causes the decrease of ductility, such a fracture will not occur in the beams at service loads. Because, the fracture occurred in these beams longs after the yield point. All the other specimens exhibited a very ductile behavior.

The effect of stirrup spacing on the crack distribution of the specimens is quite high. As the stirrup spacing decreases, the number of cracks increases and the crack intervals decrease. Increased energy absorption has also occurred with more cracks. In the specimens with less stirrup spacing, the cracks are spread over the whole beam face. For the specimens with more stirrup spacing, the number of cracks is low. In these specimens, the width of the cracks between the loading points and the brace regions is quite large. For this reason, the specimens with less stirrup spacing are more effective to prevent the shear behavior.

All cracks and damages occurred at the end of the experiments were recorded. They are shown in Fig. 4. When the damages and cracks in the test specimens were examined, the bending cracks occurred between the two loading points, and the bending + shear cracks occurred in the area between the loading points and the supports. Since there was no stirrup in the sample B-E1-L1, the shear fracture occurred at an angle of 45 degrees from the loading point after the yield. In this sample, the number of cracks is very low and the fracture was sudden and brittle. (Fig. 4(a)). It was observed that the width of a crack just below the loading point increased more than the 
other cracks in samples B-E1-L2, B-E2-L2 and B-E4-L3. (Fig. 4(e), Fig. 4(f), Fig. 4(j), Fig. 4(1)). In some of the studies on PP fibers in the literature, it was observed that a crack under the loading point expanded, and the fracture occurred in these regions $[10,11,39,40]$. After the beams reach their yield point, the crack gaps will try to widen further, but the fibers will not allow it. For this reason, it is thought that the energy accumulation occurs in the fibers inside the cracks, and the energy is suddenly released after the fibers break after a while. For this reason, it is predicted that a sudden break occurs. Especially after the yield point, it was observed that the crack spacing increased more in these regions because the curvature of the beam changes below the loading point. Therefore, fractures occur where the loading point is.

There were more cracks in fibrous specimens than nonfibrous specimens. In addition, it was observed that the crack widths in the fibrous specimens were considerably less than the non-fibrous specimens. This shows that the fibers can be very useful for limiting the crack width (Fig. 5).

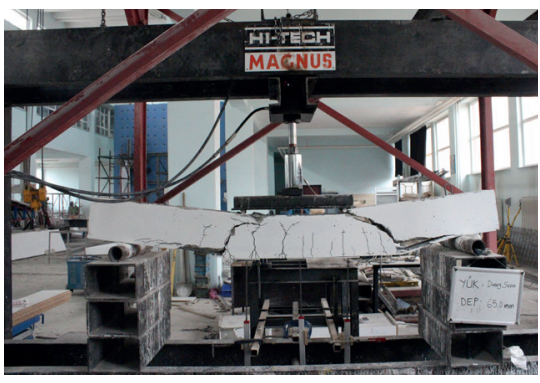

(a)

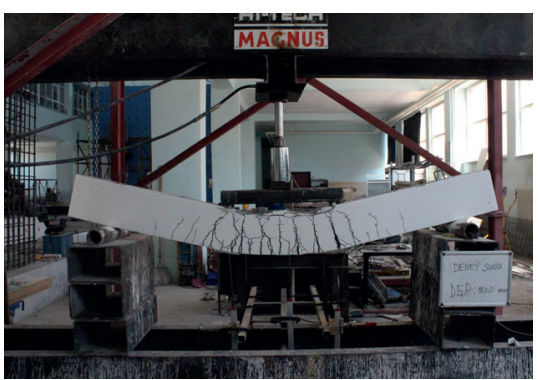

(d)

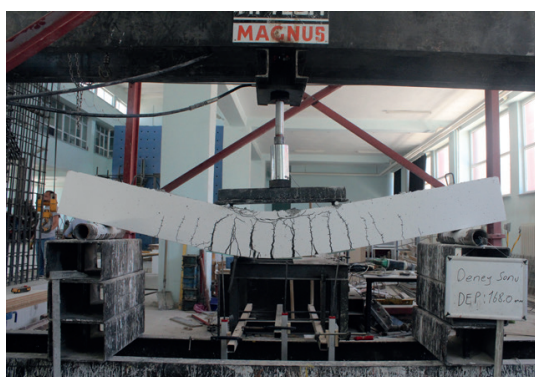

(g)

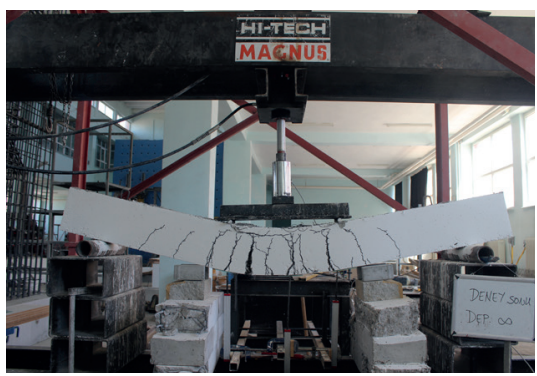

(j)

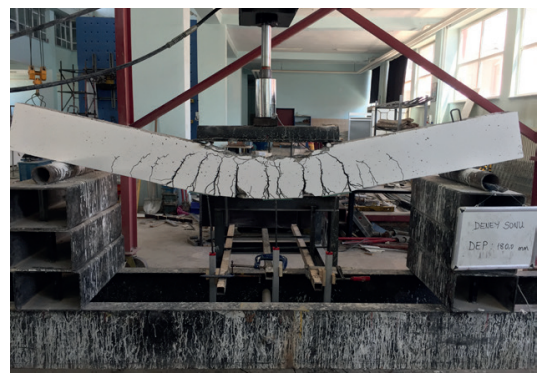

(b)

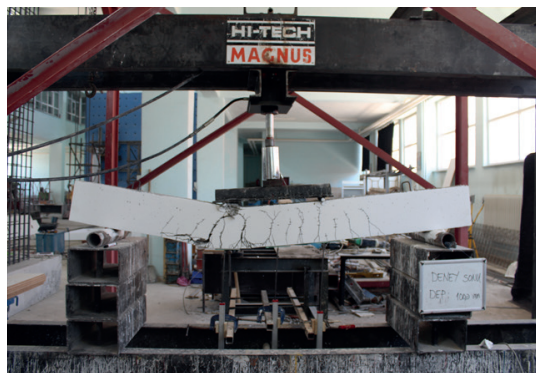

(e)

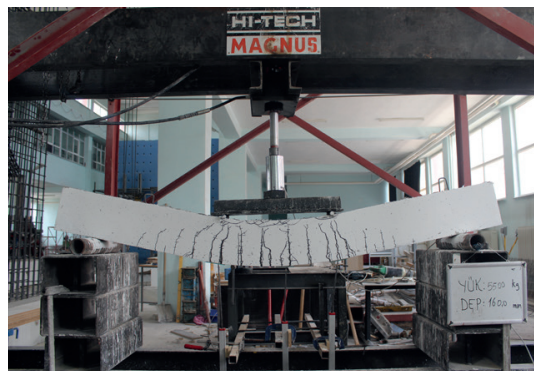

(h)

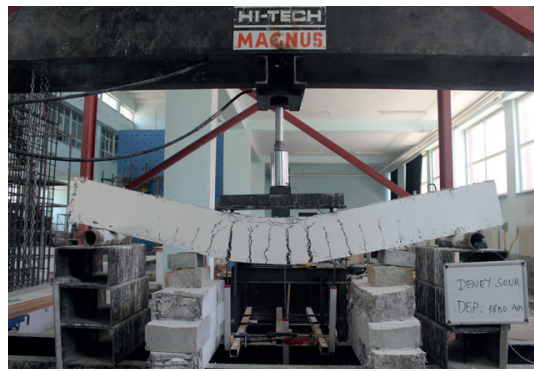

(k)

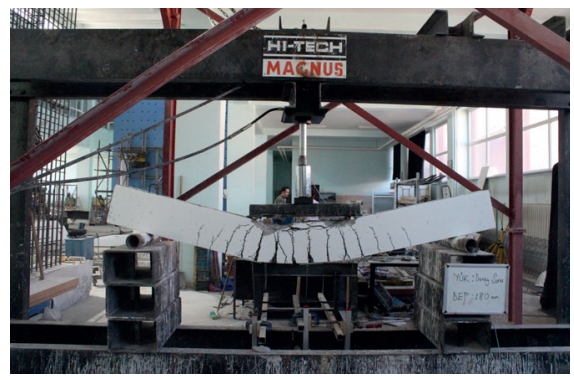

(c)

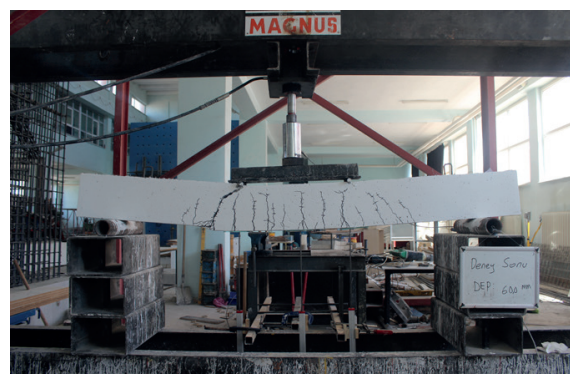

(f)

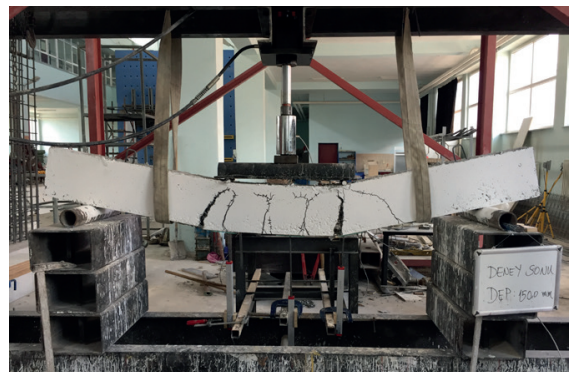

(i)

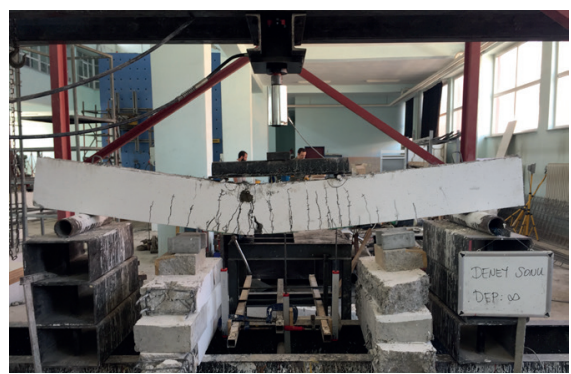

(1)

Fig. 4 Cracks and damages (a) B-E1-L1, (b) B-E2-L1, (c) B-E3-L1, (d) B-E4-L1, (e) B-E1-L2, (f) B-E2-L2, (g) B-E3-L2, (h) B-E4-L2, (i) B-E1-L3, (j) B-E2-L3, (k) B-E3-L3, (1) B-E4-L3 


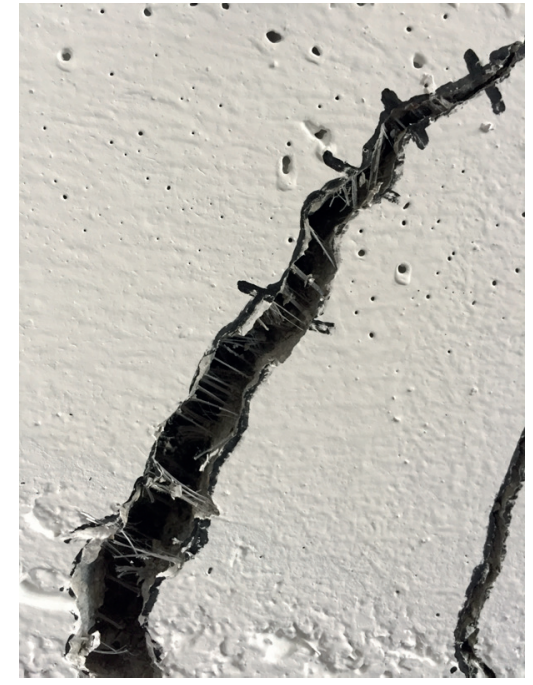

Fig. 5 Condition of fibers in cracks in the specimen

\subsubsection{Strength}

Load bearing capacities, ductility ratios, stiffness, energy absorption capacities and failure modes of the specimens are given in Table 5 and Table 6 . In addition, the loaddisplacement curves shown in Fig. 6 were plotted in order to examine the effect of the stirrup spacing on the beam behavior. In Fig. 7, the load-displacement curves are plotted in order to examine the effect of fiber on beam behavior. The load-displacement curves of all test elements are given in Fig. 8.

It can be said that the yield point of the specimens without fiber is approximately the same when Fig. 6(a) examined. In other words, it is seen that the change of the stirrup spacing does not cause a big change on the yield point. However, the non-fibrous B-E1-L1 has less load bearing capacity than the other specimens. In addition, since this specimen collapsed due to shear fracture, its ductility is considerably lower than the other specimens.

In Fig. 6(b), the effect of the stirrup spacing change on the beam behavior of the specimens with $0.125 \%$ fiber ratio is seen. The yield points are approximately at the same level in these specimens. However, it is seen that the ductility values are quite low for B-E1-L2 and B-E2-L2 specimens since shear fracture occurs on them. In addition, it is seen that the load bearing capacities of these specimens are less than those of the other specimens.

The load-displacement graphs of the specimens with $0.500 \%$ fiber content are shown in Fig. 6. When the yield points are examined, it is seen that this fiber ratio is more effective in specimens without stirrup. The load values of the B-E1-L3 test element at the yield point are $10.54 \%$, $17.33 \%, 16.58 \%$ higher than the B-E2-L3, B-E3-L3 and

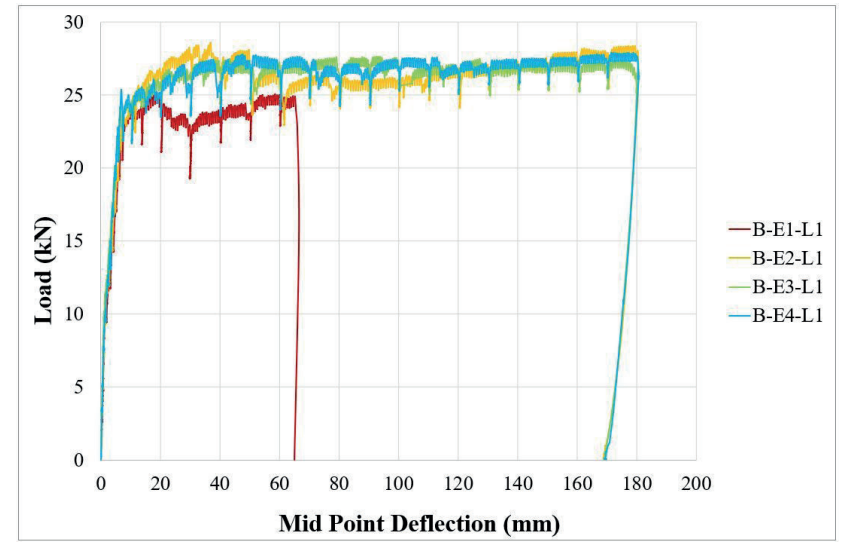

(a)

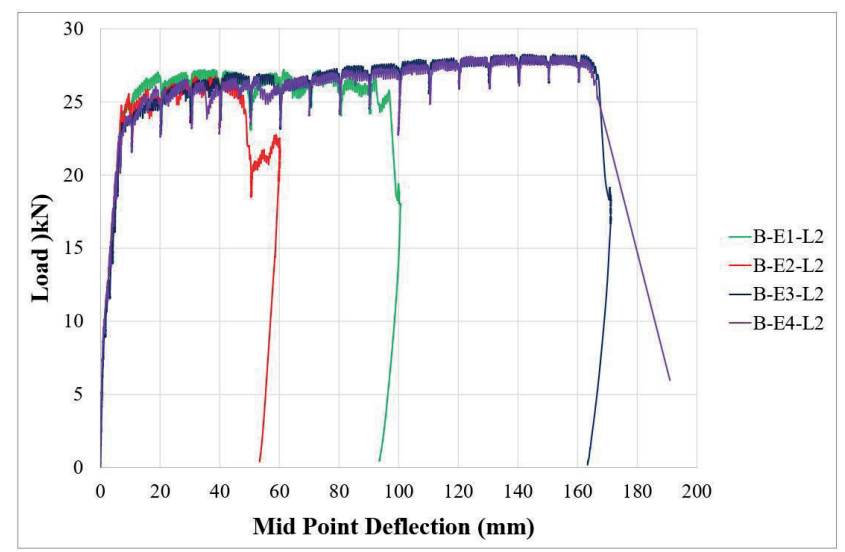

(b)

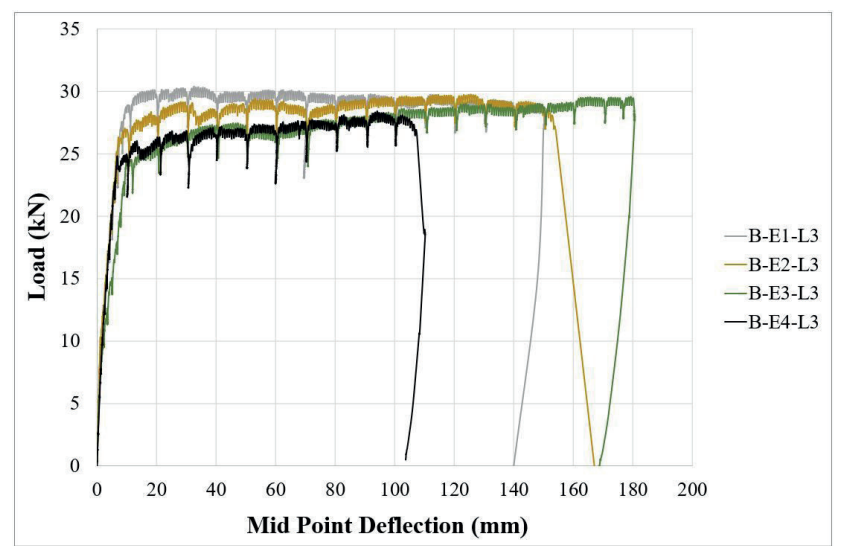

(c)

Fig. 6 Load- Mid Point Deflection curves for synthetic fiber ratio (a) $0 \%$, (b) $0.125 \%$, (c) $0.500 \%$

B-E4-L3 test elements, respectively. However, the maximum load bearing capacities are approximately the same. This shows that $0.500 \%$ fiber ratio is more effective in specimens without stirrup and in specimens with high stirrup spacing.

In order to examine the effect of fiber ratios on beam behavior, the specimens were compared with each other in Fig. 8. As seen in Fig. 7(a), both yield point and load bearing 


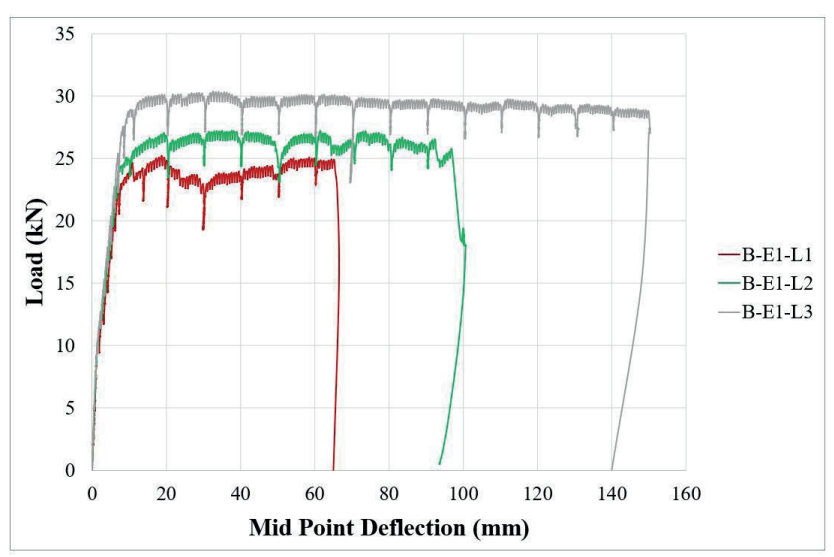

(a)

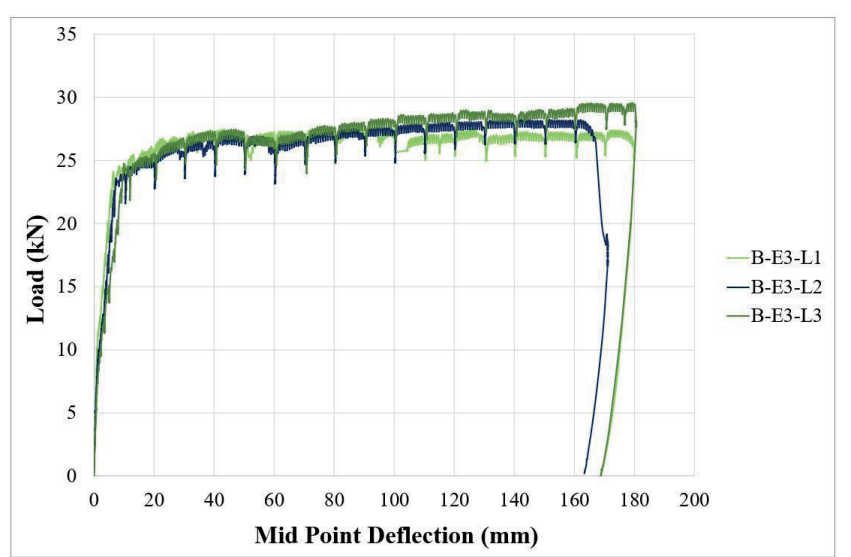

(c)

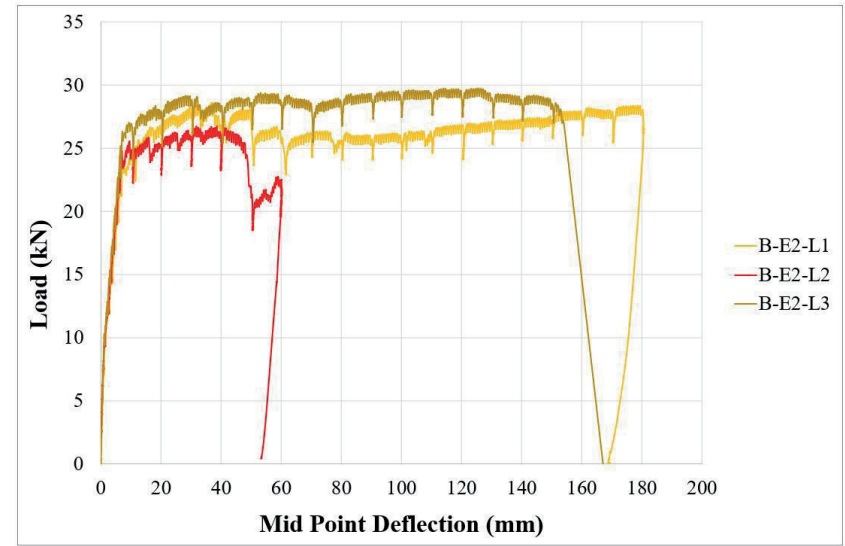

(b)

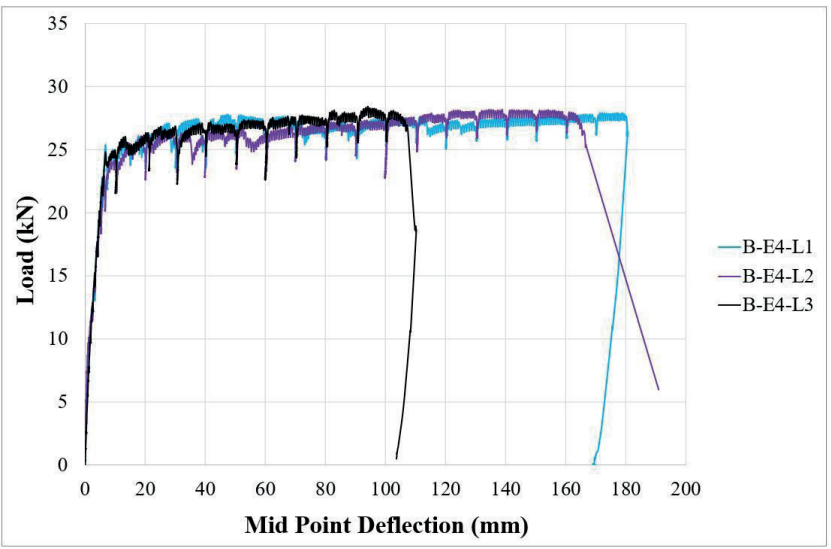

(d)

Fig. 7 Load - Mid Point Deflection curves for stirrup effect (a) E1, (b) E2, (c) E3, (d) E4

capacity of the specimens without stirrup increased with the increase of fiber ratio. The yield point of the B-E1-L3 was $16.75 \%$ and $23.37 \%$ higher than the yield point of the B-E1-L2 and B-E1-L1, respectively. Similarly, the load bearing capacity of B-E1-L3 is $17.67 \%$ and $25.29 \%$ higher than the load bearing capacity of B-E1-L2 and B-E1-L1 respectively. These results show that the beam behavior improves itself with the increase of fiber ratio in the specimens without stirrup.

In Fig. 7(b), the yield points of the specimens B-E2-L1, B-E2-L2 and B-E2-L3 are approximately the same. However, when the load bearing capacities are examined, the load bearing capacity of B-E2-L3 has $15.51 \%$ and $19.71 \%$ higher than the load bearing capacity of the B-E2-L1 and B-E2-L2, respectively. It is seen in Fig. 7(c) and Fig. 7(d) that the frequent stirrups eliminate the fiber effect. The yield points of these specimens are approximately $25 \mathrm{kN}$, and their load bearing capacities are about $28 \mathrm{kN}$. The load-displacement curves of all specimens are given comparatively in Fig. 8.

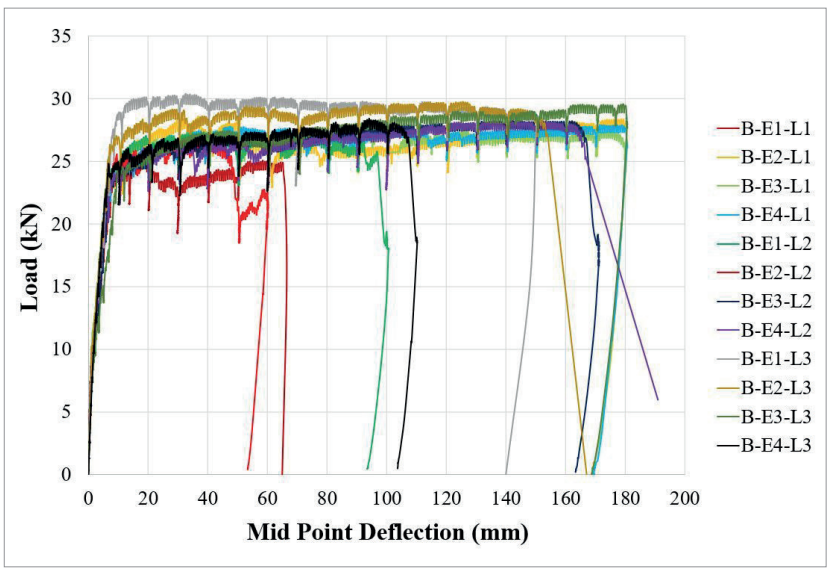

Fig. 8 Load - Mid Point Deflection curves for all specimens

\subsubsection{Stiffness}

In order to examine the effect of stirrup spacing on beam behavior, the stiffness (slope angle) curves were plotted (Fig. 9). Stiffness curves were plotted in order to examine the effect of fiber on beam behavior (Fig. 10). The stiffness curves of all specimens are given in Fig. 11. 


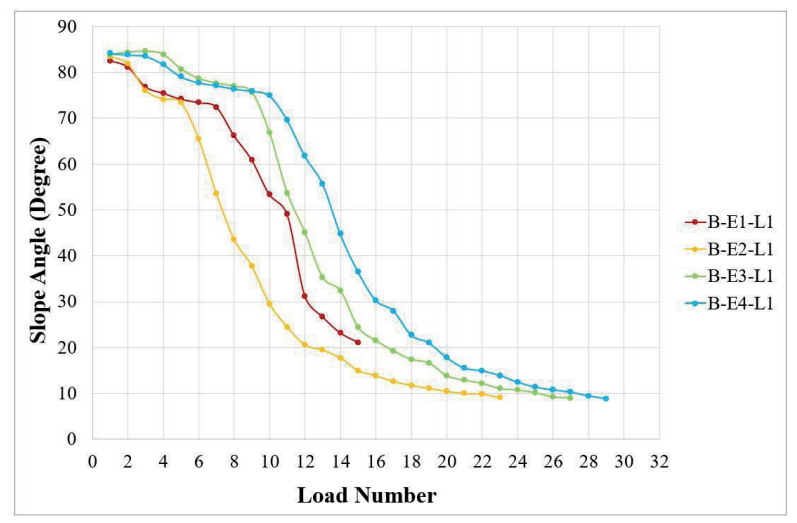

(a)

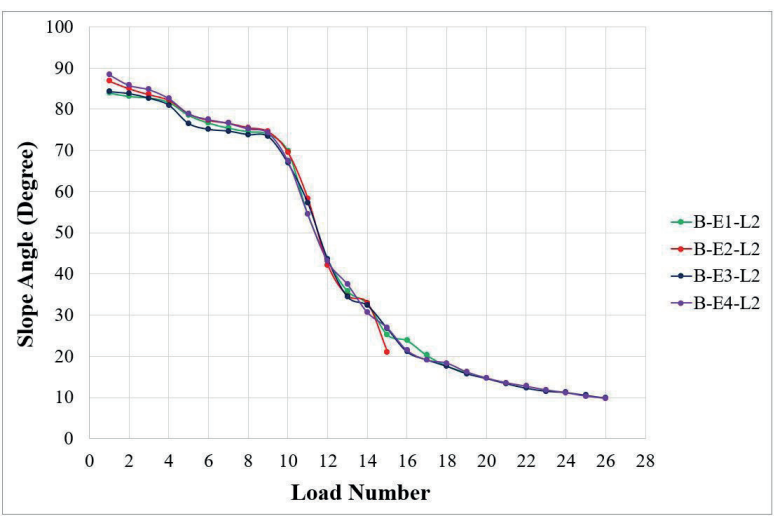

(b)

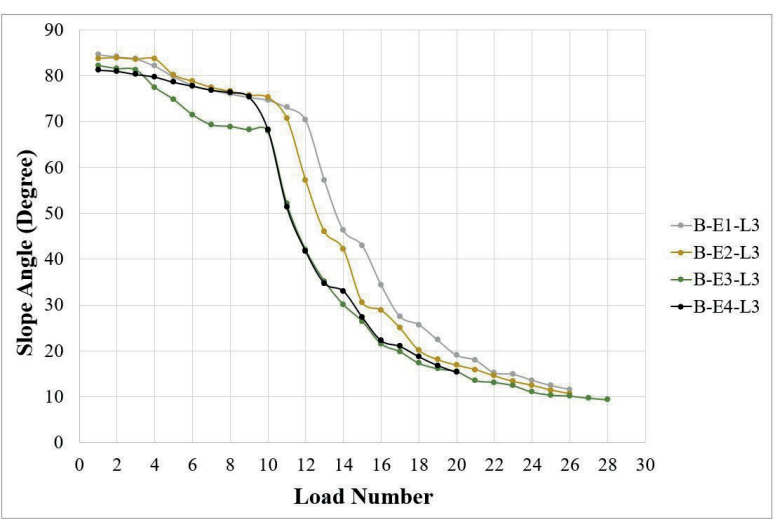

(c)

Fig. 9 Stiffness curves for synthetic fiber ratio (a) $0 \%$, (b) $0.125 \%$, (c) $0.500 \%$

In Fig. 9(a), it is seen that the stiffness of the beams decreases with the increase in the stirrup spacing. As seen in Table 6, the yield stiffness of these specimens varies between 1.89 and 2.89. In Fig. 9(b) and Fig. 9(c). It is seen that the beam stiffness is at similar levels throughout the experiments.

Fig. 10 shows the effect of fiber ratio on beam stiffness. As seen in Fig. 10(a) and Fig. 10(b), it was determined that the stiffness of the beams increased as the fiber ratio increased. However, it is seen that the stiffnesses of

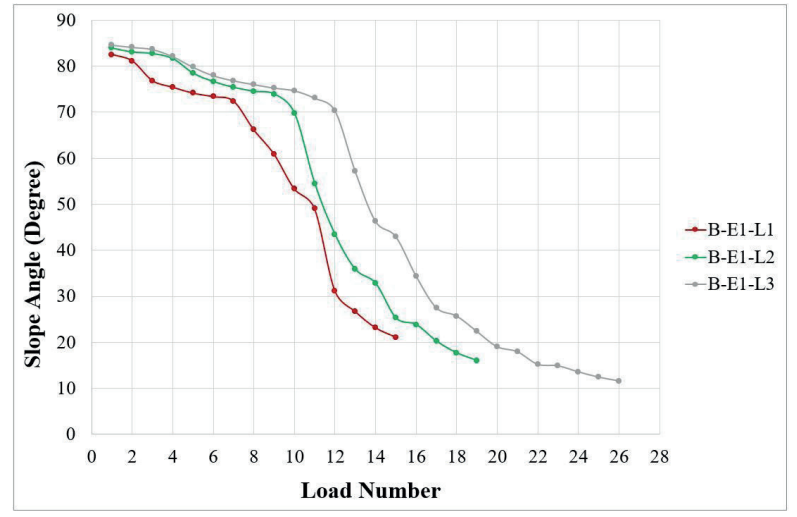

(a)

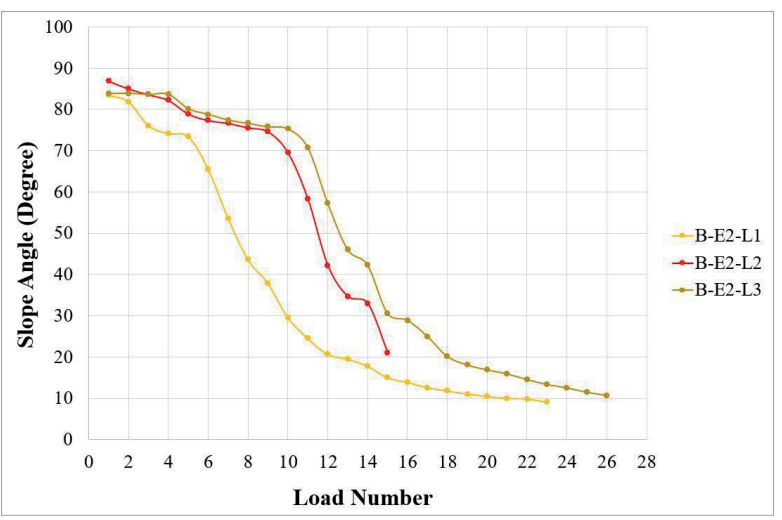

(b)

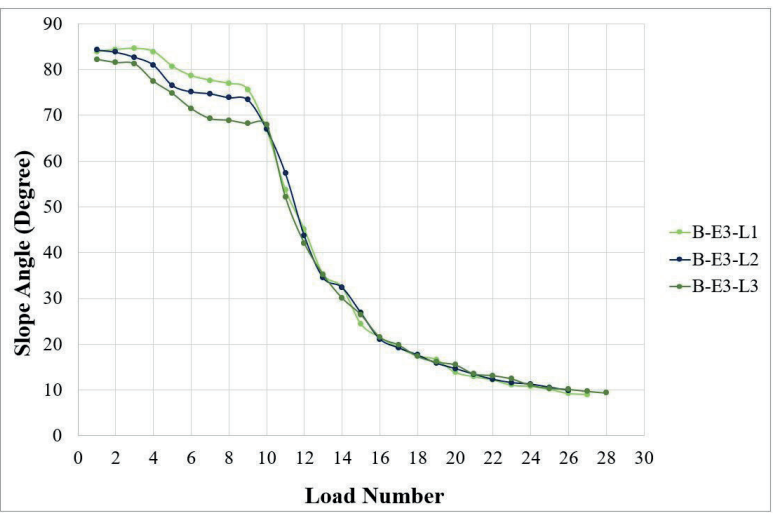

(c)

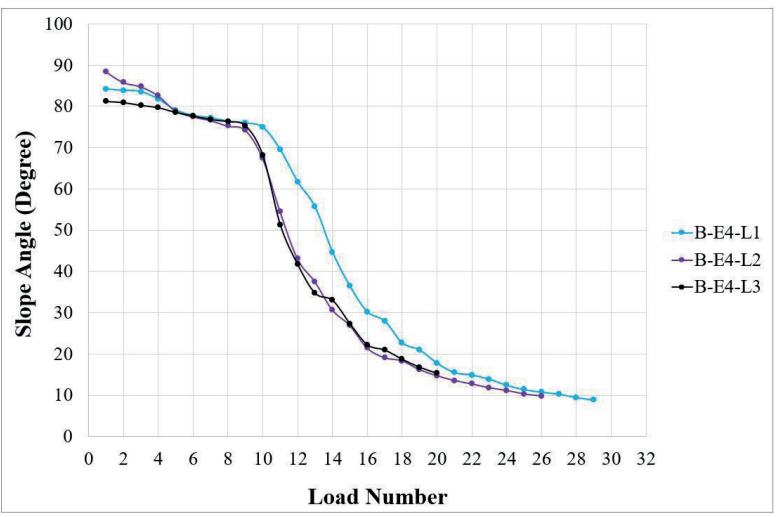

(d)

Fig. 10 Stiffness curves for stirrup effect (a) E1, (b) E2, (c) E3, (d) E4 


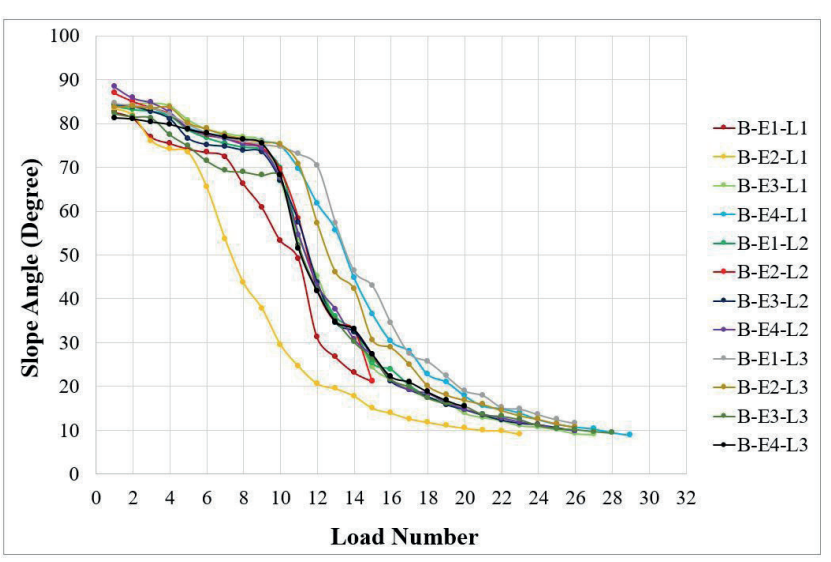

Fig. 11 Stiffness curves for all specimens

the specimens in Fig. 10(c) and Fig. 10(d) are similar. This shows that the fiber effect is more visible in the specimens with high stirrup spacing. Thus, it is seen that the fiber ratio has a significant effect on the stiffness of the specimens with low stirrup ratios and specimens without stirrup, depending on the fiber ratio. In Fig. 11, the stiffness graphs of all specimens are given comparatively.

\subsubsection{Energy dissipation}

In order to examine the effect of stirrup spacing on beam behavior, the cumulative energy graphs shown in Fig. 12 were plotted. In Fig. 13, the cumulative energy graphs were plotted to examine the fiber effect on the beam behavior. The cumulative energy graphs of all specimens are given in Fig. 14. The energy consumption capacities of the specimens without shear fracture took similar values according to the graphs. The energy consumption of the specimen with shear fracture is considerably lower than that of other specimens. Especially, it is seen that the energy consumption values of the specimens with less stirrups and of specimens without stirrup are lower than those of other specimens. It is observed that the fiber ratio effect increases the energy consumption capacity of the specimens without stirrup. As can be seen in Table 6, the energy consumption values of all specimens displaying bending behavior are in the range of 4250-4750 kNmm. For the samples at which shear fracture occurred after the yield point, B-E1-L1 has $1360 \mathrm{kNmm}, \mathrm{B}-\mathrm{E} 1-\mathrm{L} 2$ has $2300 \mathrm{kNmm}, \mathrm{B}-\mathrm{E} 2-\mathrm{L} 2$ has $1210 \mathrm{kNmm}$ and B-E4-L3 has $2800 \mathrm{kNmm}$ energy consumption values.

\subsubsection{Ductility}

The ductility rates obtained by proportioning the failure displacement to yield displacement in the specimens are given in Table 5 and Table 6 . All of the specimens reached

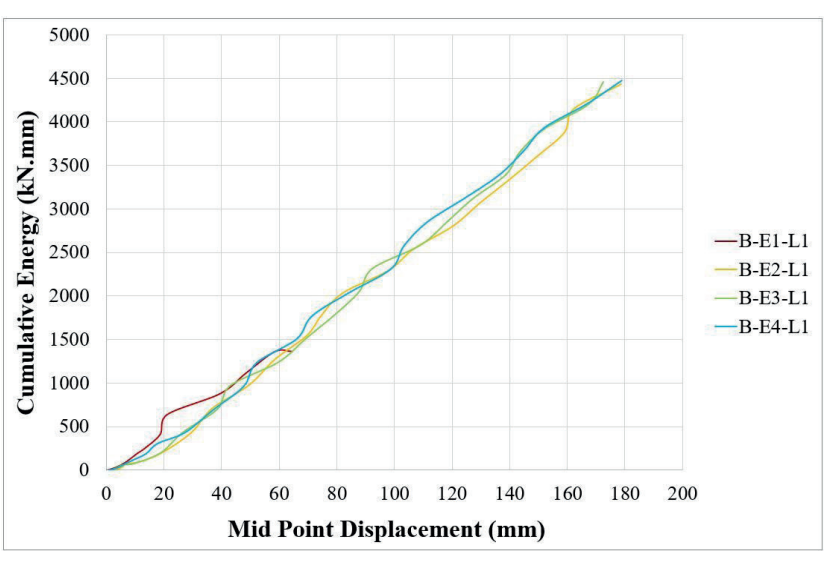

(a)

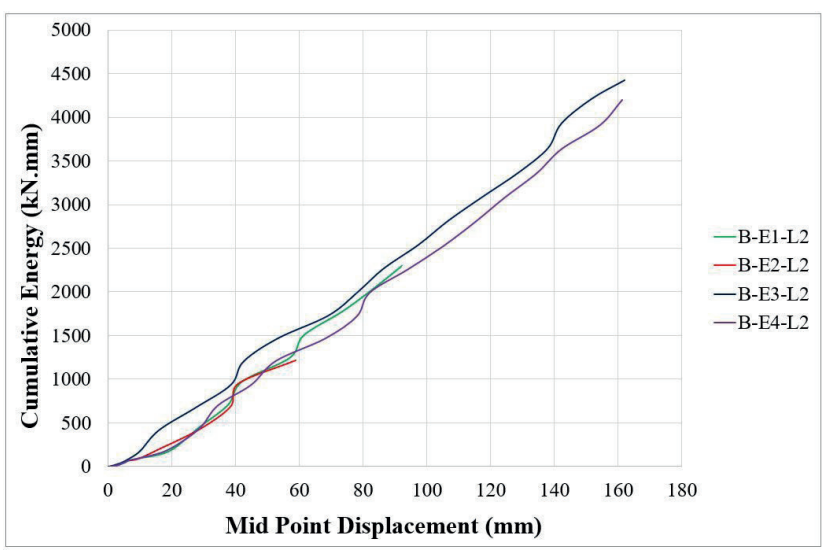

(b)

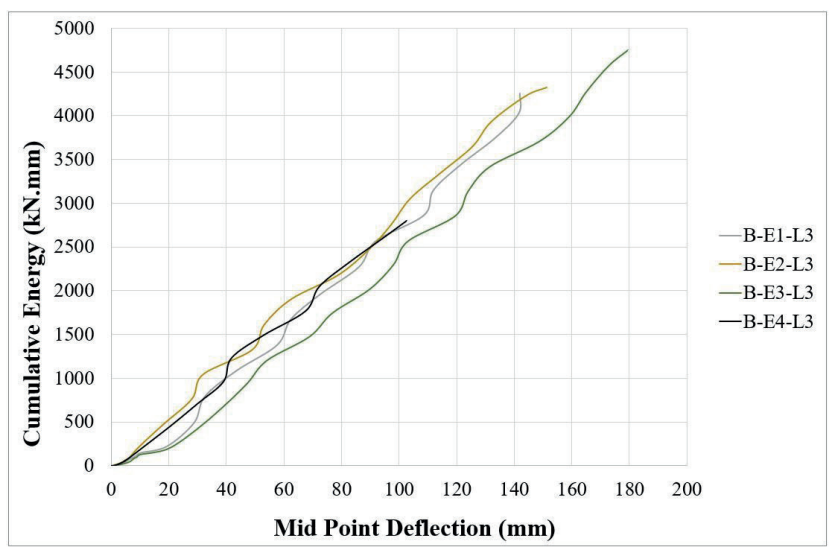

(c)

Fig. 12 Cumulative Energy curves for synthetic fiber ratio (a) $0 \%$, (b) $0.125 \%$, (c) $0.500 \%$

the yield point, and all specimens showed flexural behavior up to this point. Sometimes after the yield point was reached, the shear fracture was observed at some specimens. The ductility rates of these specimens are quite low compared to other specimens. It is seen that the ductility of the specimens without stirrup and with high stirrup spacing (B-E1-L1, B-E1-L2, B-E2-L2) is quite low compared to other specimens. 


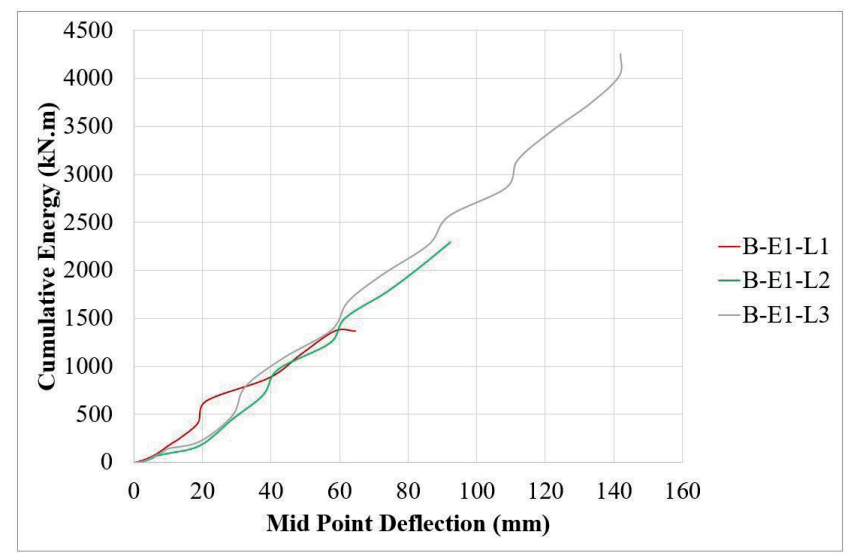

(a)

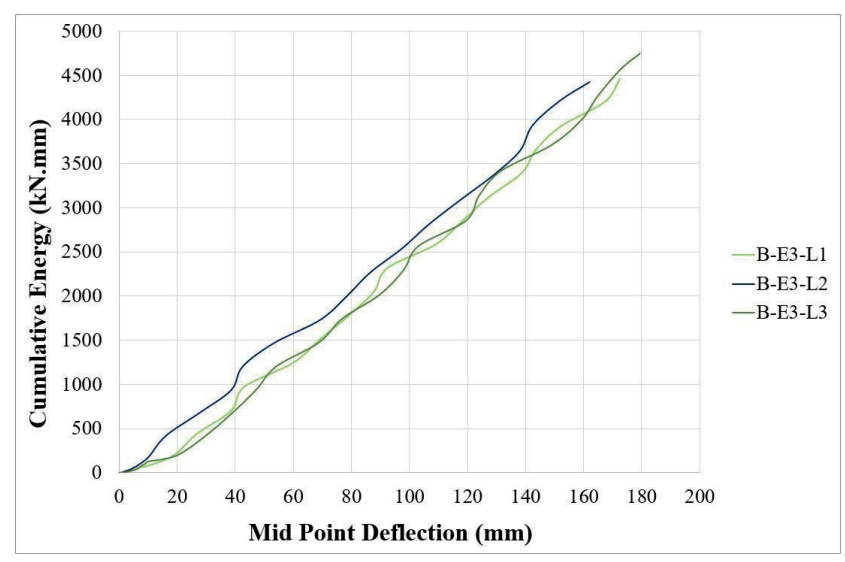

(c)

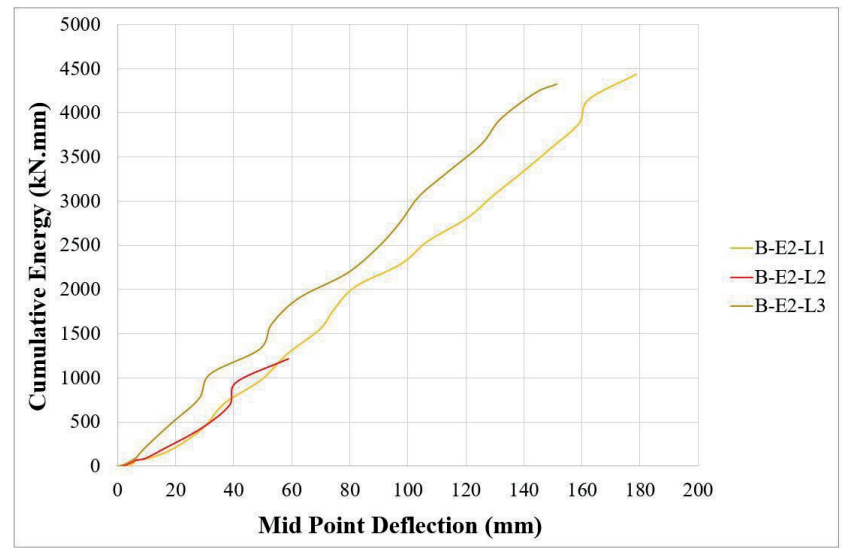

(b)

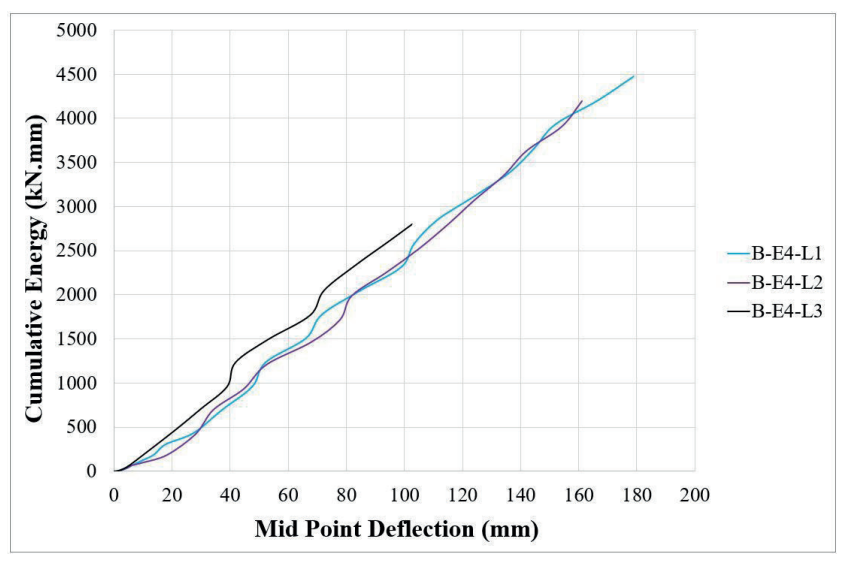

(d)

Fig. 13 Cumulative Energy curves for stirrup effect (a) E1, (b) E2, (c) E3, (d) E4

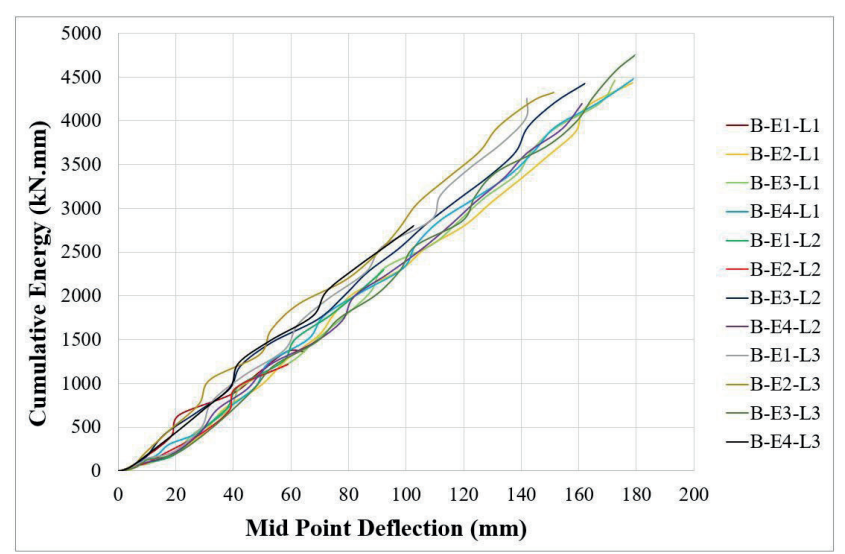

Fig. 14 Cumulative Energy curves for all specimens

In the light of all these evaluations, the load capacity and the deflection values were given in Table 5. Also, the ductility ratio, stiffness, energy values were given in Table 6. Besides these values, the failure modes of specimens were given in Table 6. In this table, while determining the failure mode, the behavior up to the yield point and the behavior after the yield point are taken as basis. Therefore, all samples exhibited flexural behavior up to the yield point. Sudden fracture occurred in some samples at the displacement levels after the yield point. The expression "Flexure + Shear" has been used in these samples because of the bending behavior up to the yield point and shear behavior after the yield point.

In the light of all this information, it was concluded that the use of PP fiber significantly changes the mechanical properties of the reinforced concrete beams. When fibers are used in beams without stirrups, the shear damage was not encountered during the collapse. In addition, the ductility ratio of the non-stirrup beams with afiber ratio of $0.125 \%$ and $0.500 \%$ is respectively $27.5 \%$ and $30.3 \%$ higher than that of non-fibrous beams. As the fiber ratio increased, it was observed that the number of cracks increased. In L2 type beams, the energy consumption value increases approximately $92 \%$ up to samples with $40 \%$ stirrup ratio, while this value is approximately $12 \%$ for L3 type beams. As the fiber ratio increases at the samples without stirrup, the yield stiffness decreases. 
However, when the stirrup beams were examined, the yield stiffness of L2 and L3 beams increased by an average of $23 \%$ compared to L1.

\section{Conclusions}

Within the scope of the study, 12 reinforced concrete beams were tested in 4-point bending mechanism. The main parameters in this study are the stirrup spacing and PP fiber ratio. The shear span to effective depth ratio (a/d) was taken as 3, and the flexure behaviors of the beams were examined during the experiments. The load bearing capacities, ductility ratios, energy consumption capacities, stiffness, failure modes and general load-displacement behaviors of 12 beams were examined. The following results were obtained in the light of the data acquired.

- Through the test elements, the shear fracture occurred at the specimens without fiber and with fibers of 0.125 $\%$ fiber ratio. However, the specimen with a fiber ratio of $0.125 \%$ showed a more ductile behavior than the other specimens. In addition, the shear fracture did not occur at the specimen without stirrup with a fiber content of $0.500 \%$, and the beam presented a bending behavior completely. This shows that the ductility of the beams increases, and the flexural behavior of the beams increases significantly with the increase of fiber ratio for the specimens without stirrup.

- It was observed that the number of cracks in the specimens increased with the decrease of the stirrup spacing. Thus, the increase in the stirrup rate increases the energy consumption. It is seen that the cracks are distributed over the whole beam surface, and the flexural behavior increased in specimens with low stirrup spacing.

\section{References}

[1] Açıkgenç, M., Arazsu, U., Alyamaç, K. E. "Farkli karişim oranlarina sahip polipropilen liffi betonlarin dayanim ve durabilite özellikleri" (Strength and durability properties of polypropylene fiber-reinforced concrete with different mixture proportions), International Journal of Technological Science, 4(3), pp. 41-54, 2012. (in Turkish) [online] Available at: https://dergipark.org.tr/tr/pub/utbd/issue/25983/273697

[2] Yavaş, A., Hasgul, U., Turker, K., Birol, T. "Effective fiber type investigation on the shear behavior of ultrahigh-performance fiber-reinforced concrete beams", Advances in Structural Engineering, 22(7), pp. 1591-1605, 2019.

https://doi.org/10.1177/1369433218820788

[3] Alsaif, A., Koutas, L., Bernal, S. A., Guadagnini, M., Pilakoutas, K. "Mechanical performance of steel fibre reinforced rubberised concrete for flexible concrete pavements", Construction and Building Materials, 172, pp. 533-543, 2018.

https://doi.org/10.1016/j.conbuildmat.2018.04.010
- Non-fibrous specimens had more cracks than the fibrous specimens. Additionally, it was observed that the crack widths in the fibrous specimens were considerably less than the non-fibrous specimens. This shows that the fibers can be very useful for limiting the crack width.

- With the increase in fiber ratio, both the yield point and the load bearing capacity of the specimens without stirrup increased. Thus, it is concluded that the beam behavior improves itself with the increase in fiber ratio.

- It has been observed that the stiffness of the beams decreases with the increase of stirrup spacing. In addition, it was determined that the stiffness of the beams increased as the fiber ratio increased. This shows that the fiber effect is more visible in the specimens with high stirrup spacing. Thus, it is seen that the fiber ratio has a significant effect on the stiffness in the specimens with low stirrup ratios and in the specimens without stirrup depending on the fiber ratio used.

- Especially, it is seen that the energy consumption values of the specimens with less stirrups and of specimens without stirrup are lower than those of other specimens. It is observed that the fiber ratio effect increases the energy consumption capacity of the specimens without stirrup.

- Although the effect of the fiber content in the specimens without stirrup or specimens with high stirrup spacing provided significant benefit to the beam behavior, the effect of the fibers in the specimens with high stirrup ratio was not clearly felt.

[4] Arslan, M. H., Doğan, G., Dabanlı, K., Özdemir, M., Divarcı, H. "Beton içinde çelik tel kullanarak betonarme binalarin deprem performansinin artirilmasi" (Improving seismic performance of reinforced concrete buildings with using steel fibers) Selcuk University Journal of Engineering Science and Technology, 3(1), pp. 1-11, 2015. (in Turkish)

https://doi.org/10.15317/Scitech.2015310832

[5] Çivici, F., Saylan, Ş. "Steel fiber reinforced concretes behaviour under biaxial flexure", Journal of Balikesir University Institute of Science and Technology, 12(1), pp. 57-64, 2010. [online] Available at: https://dergipark.org.tr/en/pub/baunfbed/issue/24283/257374

[6] Gülşan, M. E., Al-Sammarraie, K. T. F., Al Darraji, S. Y. H. "Steel fiber reinforced concrete haunched beams", The International Journal of Energy \& Engineering Sciences, 3(1), pp. 1-15, 2018. [online] Available at: https://dergipark.org.tr/en/pub/ijees/issue/ $35376 / 389684$ 
[7] Pikus, G. A. "Steel Fiber Concrete Mixture Workability", Procedia Engineering, 150, pp. 2119-2123, 2016.

https://doi.org/10.1016/j.proeng.2016.07.250

[8] Topçu, İ. B., Demirel, O. E., Uygunoğlu, T. "Polipropilen Lif Katkılı Harçların Fiziksel ve Mekanik Özelikleri" (Physical and Mechanical Properties of Polypropylene Fiber Reinforced Mortars) Journal of Polytechnic, 20(1), pp. 91-96, 2017. (in Turkish) [online] Available at: https://dergipark.org.tr/en/pub/politeknik/ issue/36869/420502\#article_cite

[9] Arslan, G., Keskin, R. S. O., Ozturk, M. "Shear behaviour of polypropylene fibre-reinforced-concrete beams without stirrups", Structures and Buildings, 170(3), pp. 190-198, 2017. https://doi.org/10.1680/jstbu.16.00202

[10] Conforti, A., Zerbino, R., Plizzari, G. A. "Influence of steel, glass and polymer fibers on the cracking behavior of reinforced concrete beams under flexure", Structural Concrete, 20(1), pp. 133-143, 2019. https://doi.org/10.1002/suco.201800079

[11] Conforti, A., Zerbino, R., Plizzari, G. A. "Assessing the influence of fibers on the flexural behavior of reinforced concrete beams with different longitudinal reinforcement ratios", Structural Concrete, 2020. https://doi.org/10.1002/suco.201900575

[12] Conforti, A., Trabucchi, I., Tiberti, G., Plizzari, G. A., Caratelli, A., Meda, A. "Precast tunnel segments for metro tunnel lining: A hybrid reinforcement solution using macro-synthetic fibers", Engineering Structures, 199, Article No. 109628, 2019. https://doi.org/10.1016/j.engstruct.2019.109628

[13] Caratelli, A., Meda, A., Rinaldi, Z., Romualdi, P. "Structural behaviour of precast tunnel segments in fiber reinforced concrete", Tunnelling and Underground Space Technology, 26, pp. 284-291, 2011.

https://doi.org/10.1016/j.tust.2010.10.003

[14] Conforti, A., Tiberti, G., Plizzari, G. A., Caratelli, A., Meda, A. "Precast tunnel segments reinforced by macro-synthetic fibers", Tunnelling and Underground Space Technology, 63, pp. 1-11, 2017. https://doi.org/10.1016/j.tust.2016.12.005

[15] Conforti, A., Ortiz-Navas, F., Piemonti, A., Plizzari, G. A. "Enhancing the shear strength of hollow-core slabs by using polypropylene fibres", Engineering Structures, 207, Article No. 110172, 2020. https://doi.org/10.1016/j.engstruct.2020.110172

[16] Nguyen, H. T. N., Tan, K. H., Kanda, T. "Effect of polypropylene and steel fibers on web-shear resistance of deep concrete hollow-core slabs", Engineering Structures, 210, Article No. 110273, 2020. https://doi.org/10.1016/j.engstruct.2020.110273

[17] Conforti, A., Minelli, F., Plizzari, G. A. "Shear behaviour of prestressed double tees in self-compacting polypropylene fibre reinforced concrete", Engineering Structures, 146, pp. 93-104, 2017. https://doi.org/10.1016/j.engstruct.2017.05.014

[18] Conforti, A., Minelli, F., Tinini, A., Plizzari, G. A. "Influence of polypropylene fibre reinforcement and width-to-effective depth ratio in wide-shallow beams", Engineering Structures, 88, pp. 12-21, 2015. https://doi.org/10.1016/j.engstruct.2015.01.037

[19] de Alencar Monteiro, V. M., Lima, L. R., de Andrade Silva, F. "On the mechanical behavior of polypropylene, steel and hybrid fiber reinforced self-consolidating concrete", Construction and Building Materials, 188, pp. 280-291, 2018.

https://doi.org/10.1016/j.conbuildmat.2018.08.103
[20] Li, B., Chi, Y., Xu, L., Shi, Y., Li, C. "Experimental investigation on the flexural behavior of steel-polypropylene hybrid fiber reinforced concrete", Construction and Building Materials, 191, pp. 80-94, 2018. https://doi.org/10.1016/j.conbuildmat.2018.09.202

[21] Sahoo, D. R., Maran, K., Kumar, A. "Effect of steel and synthetic fibers on shear strength of RC beams without shear stirrups", Construction and Building Materials, 83, pp. 150-158, 2015. https://doi.org/10.1016/j.conbuildmat.2015.03.010

[22] Furlan, Jr., S., de Hanai, J. B. "Shear behavior of fiber reinforced concrete beams", Cement and Concrete Composites 19, pp. 359366, 1997.

https://doi.org/10.1016/S0958-9465(97)00031-0

[23] Alam, M. S., Hussein, A. "Relationship between the shear capacity and the flexural cracking load of FRP reinforced concrete beams", Construction and Building Materials, 154, pp. 819-828, 2017. https://doi.org/10.1016/j.conbuildmat.2017.08.006

[24] Kodur, V., Solhmirzaei, R., Agrawal, A., Aziz, E. M., Soroushian, P. "Analysis of flexural and shear resistance of ultra high performance fiber reinforced concrete beams without stirrups", Engineering Structures, 174, pp. 873-884, 2018. https://doi.org/10.1016/j.engstruct.2018.08.010

[25] Pawłowski, D., Szumigała, M. "Flexural behaviour of full-scale basalt FRP RC beams - experimental and numerical studies", Procedia Engineering, 108, pp. 518-525, 2015. https://doi.org/10.1016/j.proeng.2015.06.114

[26] Qeshta, I. M. I., Shafigh, P., Jumaat, M. Z. "Flexural behaviour of RC beams strengthened with wire mesh-epoxy composite", Construction and Building Materials, 79, pp. 104-114, 2015. https://doi.org/10.1016/j.conbuildmat.2015.01.013

[27] Sahoo, D. R., Bhagat, S., Reddy, T. C. V. "Experimental study on shear-span to effective-depth ratio of steel fiber reinforced concrete T-beams", Materials and Structures, 49, pp. 3815-3830, 2016. https://doi.org/10.1617/s11527-015-0756-6

[28] Yang, Y., Xue, Y., Yu, Y., Ma, N., Shao, Y. "Experimental study on flexural performance of partially precast steel reinforced concrete beams", Journal of Constructional Steel Research, 133, pp. 192-201, 2017. https://doi.org/10.1016/j.jcsr.2017.02.019

[29] Yoo, D.-Y., Yang, J.-M. "Effects of stirrup, steel fiber, and beam size on shear behavior of high-strength concrete beams", Cement and Concrete Composites, 87, pp. 137-148, 2018. https://doi.org/10.1016/j.cemconcomp.2017.12.010

[30] Yousef, A. M., Tahwia, A. M., Marami, N. A. "Minimum shear reinforcement for ultra-high performance fiber reinforced concrete deep beams", Construction and Building Materials, 184, pp. 177-185, 2018.

https://doi.org/10.1016/j.conbuildmat.2018.06.022

[31] Lee, D., Han, S.-J., Joo, H.-E., Kim, K. S., Zhang, D., Kim, J. "Shear crack concentration in reinforced concrete beams subjected to shear and flexure", Advances in Structural Engineering, 23(11), pp. 23052317, 2019. https://doi.org/10.1177/1369433219895911

[32] Lu, Z.-H., Li, H., Li, W., Zhao, Y.-G., Tang, Z., Sun, Z. "Shear behavior degradation and failure pattern of reinforced concrete beam with chloride-induced stirrup corrosion", Advances in Structural Engineering, 22(14), pp. 2998-3010, 2019. https://doi.org/10.1177/1369433219855917 
[33] Li, G., Wang, B., Zhou, M. "Study on Flexural Properties of Reinforced Spontaneous Combustion Gangue Concrete Beams", Periodica Polytechnica Civil Engineering, 62(1), pp. 206-218, 2018. https://doi.org/10.3311/PPci.10647

[34] Krishnaraja, A. R., Kandasamy, S. "Flexural Performance of Hybrid Engineered Cementitious Composite Layered Reinforced Concrete Beams", Periodica Polytechnica Civil Engineering, 62(4), pp. 921929, 2018.

https://doi.org/10.3311/PPci.11748

[35] Cladera, A., Marí, A. R. "Experimental study on high-strength concrete beams failing in shear", Engineering Structures, 27, pp. 15191527, 2005.

https://doi.org/10.1016/j.engstruct.2005.04.010

[36] Sin, L. H., Huan, W. T., Islam, M. R., Mansur, M. A. "Reinforced Lightweight Concrete Beams in Flexure", ACI Structural Journal, 108(1), pp. 3-12, 2011.

https://oi.org/10.14359/51664197
[37] Unal, A., Kamanli, M., Cengiz, S. "Effect of Stirrup Ratio on the Shear Behavior of 1/2 Scale RC Beams", International Journal of Structural and Civil Engineering Research, 7(4), pp. 309-313, 2018. https://doi.org/10.18178/ijscer.7.4.309-313

[38] CEN "EN 14651Test method for metallic fibre concrete - Measuring the flexural tensile strength", CEN, Brussels, Belgium, 2005.

[39] Schumacher, P. "Rotation Capacity of Self-Compacting Steel Fiber Reinforced Concrete", PhD thesis, Delft University of Technology, 2006.

[40] Werzbrger, S., Karinski, Y. S., Dancygier, A. N. "Quantification of cracking localization in fibre-reinforced concrete beams", IOP Conference Series: Materials Science and Engineering, 246(1), Article No. 012024, 2017. https://doi.org/10.1088/1757-899X/246/1/012024 